УДК 539.12.047:598.2

РАДІОБІОЛОГІЯ ТА РАДІОЕКОЛОГІЯ

https://doi.org/10.15407/jnpae2015.03.287

\author{
V. A. Gaychenko, O. Yu. Krainiuk \\ National University of Life and Environmental Sciences of Ukraine, Kyiv
}

\title{
PECULIARITIES OF ABSORBED DOSE FORMING IN SOME WILD ANIMALS IN CHORNOBYL EXCLUSION ZONE
}

\begin{abstract}
Based on field researches conducted in the exclusion zone of the Chernobyl nuclear power plant in the years after the accident, identified the peculiarities of formation absorbed doses in animals of different taxonomic and ecological groups that live in conditions of radioactive contamination of ecosystems. Was shown importance of consideration of radiation features on wild animals according to their life cycle, conditions and ways of life. Was displayed data about the importance of different types of irradiation according to the period of stay the animals in the ground, in burrows and nests. Was reviewed the questions about value of external and internal radiation in absorbed dose of different types of wildlife. Was shown the results of the calculation of the absorbed dose of bird embryos from egg shell.

Keywords: absorbed dose, wild animals, murine rodents, birds, ungulates, $\gamma$-irradiation, $\beta$-irradiation.
\end{abstract}

Effects of ionizing radiation primarily associated with the absorbed dose in organs and tissues [13]. In chronic exposure, uneven over time, and in the distribution of radionuclides in organs and tissues of animals, because that characteristic radiation of biological objects that were exposed to contamination in Chernobyl emissions, this time there is no single value that adequately reflects the biological effects arising. In this situation, to assess the hazards of radiation, such as human or concept using the average effective dose equivalent, or the concept of critical organ; for the population - the collective equivalent dose.

Unlike laboratory animals, for wild ones are not enough sufficient experimental data to determine the contribution of individual factors weighing of a cumulative effect, especially with regard to their way of life and, therefore, applying to the calculation of the average absorbed dose following approaches for them incorrectly. Study of doserelated radiobiological effects in different ecological groups of animals also requires consider the fact, that the magnitude of doses, both in external and in internal irradiation, in addition to the characteristics of the sources, significantly influences the biological characteristics of the animals, the structure of their body, lifestyle and behavior in the wild. That is why the formation of doses in natural conditions has both physical and biological meaning.

It is well known that the most important physical characteristics of the field irradiation source and source in formation of radiation dose and biological effects in wild animals living in contaminated areas are dose of external $\beta$ - and $\gamma$-irradiation in the field of housing, specific feed radioactivity and radionuclide composition of fallouts. Among the biological and ecological characteristics of objects, the most important are mode of activity, the geometric dimensions of body, organs and tissues, features of nutrition, behavior, etc.
Standard indicators of radiation situation on the ground are the rate of exposure or absorbed dose of $\gamma$-radiation at $1 \mathrm{~m}$ above the ground, fallout of radionuclide composition and their specific surface activity. In addition to these parameters it is necessary to measure the absorbed dose rate of $\beta$-radiation and specific activity of animals feed.

That shows principles of study of radiation doses let's make a simple transition from data about radiation situation on the ground to absorbed doses of $\beta$ - and $\gamma$-irradiation in organs and tissues of animals. For example, for East European voles, who lives in the Chernobyl exclusion zone have been established conversion factors from the exposure dose of $\gamma$-radiation at $1 \mathrm{~m}$ above the ground to average daily absorbed dose rate of $\beta$ - and $\gamma$-irradiation throughout the body $\left(\mathrm{K}_{1}=1.125 \mathrm{cGy} \cdot 10^{-3} / \mathrm{mR}\right)$ to the absorbed dose rate of $\beta$-irradiation on the surface of the body and in the lining of the large parts of the gastrointestinal tract $\mathrm{K}_{2}=11.33, \mathrm{~K}_{3}=0.09 \mathrm{cGy} \cdot 10^{-3} / \mathrm{mR}$ ).

Using of these methods allows calculating the doses of irradiating of Eastern voles and field mice, as representatives of different trophic levels as well as modeling species of passerine birds - great tit and field sparrow.

\section{The materials and methods}

Work was carried out in different model plots of the Chernobyl exclusion zone during the period from 1986 to 2000. Absorbed doses were determined with the help of specially designed LiF dosimeters, in a steel capsule with a wall's thickness of $1.5 \mathrm{~mm}$ and without it, which made it possible to define separately doses of $\beta$ - and $\gamma$-radiation. The dosimeters were placed on the soil surface of experimental plots, in passes of burrows and in chambers of myomorphic rodents, in artificial nests of birds and in the trees next to nests. Determination of the specific activity

(C) V. A. Gaychenko, O. Yu. Krainiuk, 2015 
of organs and tissues of wild animals was delivered by the scintillation $\gamma$-spectrometer ORTEC with $\mathrm{NaI}$ (Tl) detector.

\section{The results and discussion}

The Table 1 presents the calculation of absorbed doses of myomorphic rodents that live in open habitats of exclusion zone near settlements Cherevach, Zalissia, Kopachi and Chystohalivka that vary in the density of soil contamination and radionuclide composition of fallouts.

Table 1. The absorbed doses of murine rodents at external and internal exposure on four model plots in the exclusion zone

\begin{tabular}{|c|c|c|c|}
\hline \multirow{3}{*}{ Plot } & \multicolumn{3}{|c|}{ Average daily dose, $10^{-3} \mathrm{cGy} /$ day } \\
\hline & \multicolumn{2}{|c|}{ external } & \multirow{2}{*}{$\begin{array}{c}\text { internal } \\
\beta \text {-irradiation }\end{array}$} \\
\hline & $\gamma$-irradiation & $\beta$-irradiation & \\
\hline Cherevach & 2.4 & 24 & 0.043 \\
\hline Zalissia & 2.16 & 20.6 & 0.043 \\
\hline Kopachi & 14.4 & 151 & 0.124 \\
\hline Chystohalivka & 137 & 1440 & 5.05 \\
\hline
\end{tabular}

So decisive in forming the absorbed dose of rodents is external $\gamma$ - and $\beta$-irradiation, due to the size of the animal, approximately amounting to run of

$\beta$-particles in biological tissue, and the contribution of internal $\beta$-irradiation is insignificant (Table 2).

Table 2. Eastern European vole absorbed doses due to 6 months in 1990, cGy

\begin{tabular}{|l|c|c|c|c|}
\hline \multicolumn{1}{|c|}{ Plot } & $\begin{array}{c}\text { External } \\
\gamma \text {-irradiation }\end{array}$ & $\begin{array}{c}\text { External } \\
\beta \text {-irradiation }\end{array}$ & $\begin{array}{c}\text { Internal } \\
\beta \text {-irradiation }\end{array}$ & $\begin{array}{c}\text { Additional } \\
\beta \text {-irradiation } \\
\text { GI tract }\end{array}$ \\
\hline Cherevach & 0.67 & 2.9 & 0.008 & - \\
\hline Zalissia & 0.56 & 2.4 & 0.008 & - \\
\hline Kopachi & 3.9 & 78 & 0.022 & 0.013 \\
\hline Chystohalivka & 27 & 243 & 0.91 & 0.53 \\
\hline
\end{tabular}

Similar results were obtained by other radiation of birds during movement and feeding researchers in the Chernobyl exclusion zone [14 17]. Assessment of external dose rate in birds, like in work with murine rodents, conducted based on readings of dosimeters, which were installed in artificial nests and in trees for a period of $84-102$ days. Due to the fact that the determination of $\beta$ practically impossible, it was assumed that in this case the contribution of $\beta$-radiation is the same as in stay that in the nest. In flight, the dose is reduced in proportion to the distance from the source with no external $\beta$-irradiation (Table 3).

Table 3. Rate of absorbed doses of birds in their locations, $\mathbf{1 0}^{-3} \mathrm{cGy} / \mathrm{h}$

\begin{tabular}{|l|c|c|c|c|c|c|c|c|}
\hline \multirow{2}{*}{ Plot } & \multicolumn{2}{|c|}{ Nest } & \multicolumn{2}{c|}{ Nutrition } & \multicolumn{2}{c|}{ In fly } & \multicolumn{2}{c|}{ On ground } \\
\cline { 2 - 9 } & $R_{\gamma}$ & $R_{\beta}$ & $R_{\gamma}$ & $R_{\beta}$ & $R_{\gamma}$ & $R_{\beta}$ & $R_{\gamma}$ & $R_{\beta}$ \\
\hline Kopachi & 1.75 & 0.58 & 1.75 & 0.58 & 0.85 & - & 2.17 & 6.0 \\
\hline Novoshepelytske forestry & 1.93 & 0.58 & 1.93 & 0.58 & 0.96 & - & 2.14 & 5.9 \\
\hline Izumrudne & 1.93 & 0.58 & 1.93 & 0,58 & 0.96 & - & 2.7 & 7.4 \\
\hline
\end{tabular}

The estimated absorbed doses of adult birds in considering of features of their being in polluted different biogeocenoses of exclusion zone with coenoses are shown in Table 4.

Table 4. Absorbed doses in adult birds in 1990, cGy

\begin{tabular}{|l|c|c|c|c|c|c|}
\hline \multirow{3}{*}{ Plot } & \multicolumn{4}{|c|}{ Great tit } & \multicolumn{2}{c|}{ A field sparrow } \\
\cline { 2 - 8 } & \multicolumn{2}{|c|}{ migratory } & \multicolumn{2}{c|}{ all year long } & \multicolumn{2}{c|}{ all year long } \\
\cline { 2 - 8 } & $D_{\gamma}$ & $D_{\beta}$ surface & $D_{\gamma}$ & $D_{\beta \text { surface }}$ & $D_{\gamma}$ & $D_{\beta \text { surface }}$ \\
\hline Kopachi & 7.9 & 3.4 & 14.2 & 6.2 & 14.2 & 6.2 \\
\hline Novoshepelytske forestry & 8.7 & 3.5 & 15.6 & 6.3 & 15.6 & 6.3 \\
\hline Izumrudne & 8.8 & 3.7 & 15.8 & 6.7 & 15.8 & 6.7 \\
\hline
\end{tabular}

Experiments and calculations indicate that, unlike largest doses creates external $\gamma$-radiation, due to a small mammals to birds that live in hollows, the longer stay of birds in the trees than in the nest on 
the surface of the soil. B-component due to stay at the trees owing to the high mobility of the animals is small and it can be neglected.

In the study of internal radiation absorbed doses in large mammals - European hare, European roe, wild boar and elk proceeded from the assumption that ${ }^{137} \mathrm{Cs}$ in the body of these animals in a state of dynamic equilibrium, and its concentration in organs and tissues is constant throughout the year. The dose of external $\gamma$-radiation measured by the exposure dose in places of shooting of animals. The possibility of using this method is confirmed by experimental determination of absorbed dose by wild animals by EPR of tooth enamel [1, 5 - 7]. Dose that formed by external $\beta$-radiation can be neglected due to its full absorption by covering of these animals.

Calculation results lead to the conclusion that this group of animals forming absorbed dose in typical role of different internal and external $\gamma$-radiation. For animals that feed on herbaceous and woody vegetation (deer and European elk) are more relevant is internal exposure, and for hares and wild boars - external (Table 5).

Table 5. Absorbed dose of different species of mammals at the plot "Koshovka" in 1991, cGy

\begin{tabular}{|c|c|c|c|c|}
\hline Dose & Hares & Roes & Wild boars & Elks \\
\hline internal & 0.61 & 10.5 & 0.16 & 2.13 \\
\hline external & 1.31 & 1.31 & 1.4 & 0.79 \\
\hline
\end{tabular}

There is some relationship between the characteristics of animal nutrition and internal exposure doses. Thus, the maximum exposure is characteristic for European roe, which fed into the growing season mainly herbaceous vegetation, and in winter-feeding on leaf defoliation and bark and branches of trees. Much smaller doses get elks, which feed mainly branches food, even smaller - hares that feed almost exclusively annual herbaceous vegetation.

The question about the absorbed dose in wild boar requires further detailed study because, nourished mostly in the litter and topsoil wild boar should have greater concentrations of ${ }^{137} \mathrm{Cs}$ in organs and tissues, although our data suggest otherwise. It is possible that in this case affects the way of life of these animals, particularly the seasonal variability of the specific activity of organs and tissues of animals [2 - 4].

The investigation of radiological effects on birds that living in the Chernobyl exclusion zone [ $8-10$, 18 - 20] revealed a significant effect of ionizing radiation on reproduction success of almost all ornithological complexes and especially birds of wetlands complex and some passerines.

Radiometric and radiochemical research of specific activity of shell eggs of birds of various ecological levels showed very high concentration of ${ }^{90} \mathrm{Sr}$, comparable with activity of radioactive waste (around $10^{4} \mathrm{~Bq} / \mathrm{kg}$ ) in connection with which there was the problem of determining the possible impacts, in particular - study the effect incorporated in shell eggs radioactive strontium on the embryo that develops [11,12].

Model of calculation of equivalent dose embryos of birds in the early stages of embryogenesis in continuous exposure of ${ }^{90} \mathrm{Sr}$ [12] allowed to consider the possibility of calculating the absorbed dose to the embryo by remnants of shell, that is, without removing the eggs from the nest, and show that the formation of the dose is only occurs on the surface of eggs, located in the vicinity of the embryo taking into account the electron absorption by the layer of protein and the yolk.

Naturally, that with the growth of the embryo and occupation of his all volume of eggs radiation process change significantly. At the same time the radiation in the early stages of embryogenesis leads to its suppression and the consequent emergence of a significant number of eggs without embryo what stated by various authors $[8,9,18-20]$.

In the Table 6 the mean absorbed doses for bird embryos of four species of passerine birds with approximately equal linear dimensions of eggs are presented. In the calculations carried assumption that if the distance from the shell to the embryo more than the average run of the electron - dose is considered small.

Table 6. Average absorbed doses on embryos of birds on 7 day of incubation

\begin{tabular}{|c|l|c|c|}
\hline \multirow{2}{*}{ Place of sampling } & \multicolumn{1}{|c|}{ Species } & Shell surface activity, $10^{-9} \mathrm{Ci} / \mathrm{cm}^{2}$ & $\begin{array}{c}\text { Absorbed dose for } 7 \text { days, } \\
10^{-3} \mathrm{cGy}\end{array}$ \\
\hline \multirow{4}{*}{ Novoshepelytske forestry } & pied flycatcher & $0.14 \pm 0.08$ & $13.14 \pm 1.62$ \\
\cline { 2 - 4 } & gray flycatcher & 0.939 & 88.488 \\
\cline { 2 - 4 } & blue tit & $0.31 \pm 0.1$ & $107.14 \pm 35.63$ \\
\cline { 2 - 4 } & great tit & $0.132 \pm 0.08$ & $16.6 \pm 0.98$ \\
\hline \multirow{5}{*}{ Izumrudne } & pied flycatcher & 1.124 & 395.66 \\
\cline { 2 - 4 } & gray flycatcher & $0.796 \pm 0.15$ & $73.07 \pm 3.96$ \\
\cline { 2 - 4 } & blue tit & 0.08 & $78.859 \pm 14.77$ \\
\cline { 2 - 4 } & great tit & $0.257 \pm 0.09$ & $9.178 \pm 1.712$ \\
\cline { 2 - 4 } & field sparrow & 0.098 & \\
\hline
\end{tabular}


Depending on the timing of incubation absorbed dose will only increase and could reach 1 - 2 Gy [21], cannot distinguish on breeding success.

Thus, the formation of the absorbed dose of wild animal species that live in conditions of radioactive contamination of biogeocenosis leading role played the environmental characteristics of each group of animals, primarily - living conditions, nutrition, activity and reproduction, and the density of pollution and various types of radiation.

For large, mobile species of open spaces and forests, the predominant role played external $\gamma$-irradiation, way of getting food and significant individual feed areas. Also important the type of nutrition - animals that consume in the growing season shoots of shrubs and in autumn - winter period leaf foliage (European roe) indicate an increase of the participation of internal exposure.

For small rodents that throughout the life cycle living in the most contaminated layers of soil, there is ten times more value of external $\beta$-radiation than $\gamma$-radiation, which is explained smaller, comparable with the run of $\beta$-particle, size of the body.

For birds that live in hollows, it is essential external $\gamma$-radiation and $\beta$-component with nesting material. For migratory birds and wandering species, absorbed dose almost is doubled lower due to exposure of radiation only when during nesting. However, the growth of bird embryos under continuous exposure of ${ }^{90} \mathrm{Sr}$ from shell of eggs leads to a partial reduction in breeding success of birds.

\section{REFERENCES}

1. Bugai A., Baryakchtar V.G., Baran N. et al. ESR/tooth enamel dosimetry application to Chernobyl case: individual retrospective dosimetry of the liquidators and wild animals // The radiological consequences of the Chernobyl accident. - Minsk, 1996. - P. 1049 - 1052.

2. Davydchuk V., Eriksson O., Gaychenko V. et al. Transfer of Radionuclides from Forage Plants to Herbivores // Report 10, ISSN 0348-8659. - Swedish Univ. of Agricultural Sci. Uppsala, 1993. - P. 1 - 13.

3. Eriksson O., Gaychenko V., Goshchak S. et al. Evolution of the contamination in game // The radiological consequences of the Chernobyl accident. Minsk, 1996. - P. 147 - 154.

4. Jones B., Eriksson O., Gaychenko V. et al. Radionuclides transfer to wild animals // The Behaviour of Radionuclides in Natural and SemiNatural Environments: Doc. ENEA-DISP/ARA-MET. No. 6. - Roma, 1992. - P. 123 - 130.

5. Bar'yakhtar V.G., Bugaj A.A., Baran N.P. et al. // Dopovidi Akademii nauk Ukrainy. - 1994. - No. 12. P. 149 - 152. (Rus)

6. Bar'yakhtar V.G., Bugaj A.A., Gaychenko V.A. et al. Instrumental assessment of the current radioecological conditions and the radiation situation in the past in the area of the Chernobyl disaster // Prof. of IV Intern. Scientific and Technical Conf. "Itogi 8 let rabot po likvidatsii posledstvij avarii na ChAES". Chernobyl, 1996. - Vol. 1. - P. 84 - 90. (Rus)

7. Bar'yakhtar V.G., Bugaj A.A., Gaychenko V.A. et al. // Problemy Chornobyl's'koyi zony vidchuzhennya. Chornobyl'. - 1995. - No. 2. - P. 113 - 120. (Rus)

8. Gaber N.A. Changes in the number and characteristics of the breeding of passerine birds in the 30-kilometer zone of the Chernobyl Nuclear Power Plant in 1989 1992 // Book of Abstracts of the II Congress of radiobiology. - Kyiv, 1993. - Vol. 1. - P. 197. (Rus)

9. Gaber N.A. // Dopovidi Akademii nauk Ukrainy. 1993. - No. 1. - P. 123 - 127. (Rus)

10. Gaychenko V.A. Radiobiological consequences of the Chernobyl accident in populations of wild animals in the exclusion zone: Abstract of thesis of Doctor of biology science. - Kyiv, 1996. - 48 p. (Ukr)
11. Gaychenko V.A., Koval' G.N., Semenyuk N.I., Gaber $N . A$. Radiation dose formation on the bird embryo in the radioactive contamination conditions // Book of Abstracts of the II Congress of radiobiology. - Kyiv, 1993. - Vol. 1. - P. 201. (Rus)

12. Gaychenko V.A., Svarichevskaya E.V., Semenyuk N.I. // Nucl. Phys. At. Energy. - 2007. - No. 3(21). - P. 76 80. (Rus)

13. Kuzin A.M. The invisible rays around us. - Moskva: Nauka, 1980. - 211 p. (Rus)

14. Maklyuk Yu.A., Gashchak S.P., Maksimenko A.M. et al. // Nucl. Phys. At. Energy. - 2007. - No. 3(21). - P. 81 -91. (Rus)

15. Maklyuk Yu.A. Accumulation features of ${ }^{90} \mathrm{Sr}$ and ${ }^{137} \mathrm{Cs}$ and doses in murine and soricomorpha of the exclusion zone and zone of unconditional (obligatory) resettlement: $\mathrm{PhD}$ Abstract of thesis. - Kyiv, 2008. 21 p. (Ukr)

16. Maklyuk Yu.A., Maksimenko A.M., Gashchak S.P. et al. // Ekologiya. - 2007. - No. 3. - P. 198 - 206. (Rus)

17. Maklyuk Yu.A., Gashchak S.P., Lipskaya A.I. et al. // Nucl. Phys. At. Energy. - 2006. - No. 2(18). - P. 115 123. (Rus)

18. Mikityuk A.Yu. Change wetland bird communities of Kyiv Polissya because of radiation factor // Book of Abstracts of the I Intern. Conf. "Biologicheskie i radioekologicheskie aspekty posledstvij avarii na ChAES". - Moskva: Nauka, 1990. - P. 70. (Rus)

19. Mikityuk A.Yu. Changing of wetland complexes status in the 30-kilometers exclusion zone of Chernobyl Nuclear Power Plant over the period 1986 - 1992 // Ekologo-faunisticheskie issledovaniya v zone Chernobyl'skoj AES. - Kyiv: Meditsina i ekologiya, 1995. - P. 36 - 46. (Rus)

20. Mikityuk A.Yu. The success of bird populations reproduction of wetland ecosystems of radiochemically polluted landscapes // Book of Abstracts of the II Congress of radiobiology. - Kyiv, 1993. - Vol. 2. - P. 686 - 687. (Rus)

21. Ryabtsev I.A., Lebedeva N.V. Radioecology of birds. Rostov-na-Donu: Bios, 1999. - 64 p. (Rus) 


\section{В. А. Гайченко, О. Ю. Крайнюк}

Національний університет біоресурсів і природокористування України, Київ

\section{ОСОБЛИВОСТІ ФОРМУВАННЯ ДОЗОВИХ НАВАНТАЖЕНЬ ДЕЯКИХ ДИКИХ ТВАРИН ЧОРНОБИЛЬСЬКОЇ ЗОНИ ВІДЧУЖЕННЯ}

На основі натурних досліджень, проведених у зоні відчуження Чорнобильської АЕС у різні роки після аварії, визначено особливості формування поглинених доз у тварин різних систематичних і екологічних груп, які живуть в умовах радіоактивного забруднення екосистем. Показано важливість урахування особливостей радіоактивного опромінення диких тварин відповідно до їхнього життєвого циклу та умов і способів життєдіяльності. Наведено дані щодо значимості різних видів опромінення відповідно до термінів перебування тварин на поверхні грунту, у норах і гніздах. Розглянуто питання співвідношення зовнішнього та внутрішнього опромінення в поглиненій дозі різних видів диких тварин. Наведено результати розрахунку поглиненої дози ембріонів горобиних птахів від шкаралупи яєць.

Ключові слова: поглинена доза, дикі тварини, мишоподібні гризуни, птахи, копитні, $\gamma$-опромінення, $\beta$-опромінення.

\section{В. А. Гайченко, О. Ю. Крайнюк}

Национальный университет биоресурсов и природопользования Украины, Киев

\section{ОСОБЕННОСТИ ФОРМИРОВАНИЯ ДОЗОВЫХ НАГРУЗОК НЕКОТОРЫХ ДИКИХ ЖИВОТНЫХ ЧЕРНОБЫЛЬСКОЙ ЗОНЫ ОТЧУЖДЕНИЯ}

На основе натурных исследований, проведенных в зоне отчуждения Чернобыльской АЭС в разные годы после аварии, определены особенности формирования поглощенных доз у животных разных систематических и экологических групп, обитающих в условиях радиоактивного загрязнения экосистем. Показана важность учета особенностей радиоактивного облучения диких животных в соответствии с их жизненным циклом и условиями и способом жизнедеятельности. Приведены данные о значимости различных видов облучения в зависимости от времени пребывания животных на поверхности почвы, в норах и гнездах. Рассмотрены вопросы соотношения внешнего и внутреннего облучения в поглощенной дозе различных видов диких животных. Приведены результаты расчета поглощенной дозы эмбрионов воробьиных птиц от скорлупы яиц.

Ключевые слова: поглощенная доза, дикие животные, мышевидные грызуны, птицы, копытные, $\gamma$-облучение, $\beta$-облучение.

Надійшла 26.08.2015

Received 26.08.2015 